\title{
Turistik Çekiciliklerin Markalaşmalarında Turist Rehberleri Üzerine Bir Araştırma*
}

\author{
A Study on Tourist Guides in Branding of Tourist Attractions
}

\author{
Öğr. Gör. İlknur MAZAN \\ Uşak Üniversitesi, Banaz Meslek Yüksekokulu, Türkiye \\ Uşak University, Banaz Vocational School, Turkey \\ E-Mail: ilknur.mazan@usak.edu.tr \\ Prof. Dr. Şuayıp ÖZDEMİR \\ Afyon Kocatepe Üniversitesi, İktisadi ve İdari Bilimler Fakültesi, Türkiye \\ Afyon Kocatepe University, Faculty of Economics and Administrative Sciences, Turkey \\ E-Mail: sozdemir@aku.edu.tr \\ $\ddot{O} z$ \\ Amaç ve Önem: Bu çalışmanın amacı turistik çekiciliklerin markalaşmalarında turist rehberlerinin \\ katkılarını ortaya koymaktır. Ülkelerin ve şehirlerin markalaşma çalışmalarının yoğun olarak \\ yürütüldüğ̈̈ günümüzde, turistik çekiciliklerin markalaştırılabilmeleri mümkün görülmektedir. $\mathrm{Bu}$ \\ bağlamda, bu çalışma ile çekiciliklerin tanınmaları ve markalaşmalarında önemli bir yeri olduğu \\ düşünülen turların başrol oyuncuları olan turist rehberlerinin görüş ve önerilerinin tespit edilmesi \\ amaçlanmaktadır. Turist rehberlerinin çekiciliklerin markalaştırılmaları sürecinde doğrudan veya \\ dolaylı olarak nasıl yer aldıkları, çekiciliklerin turistik olarak yapılandırılmalarında ve turlara dâhil \\ edilme süreçlerinde katkıda bulunup bulunmadıkları gibi konuları tespit etmeyi amaçlaması, bu \\ çalışmayı önemli kılmaktadır.
}

Yöntem: Araştırmanın evrenini Türkiye'deki turist rehberleri oluşturmaktadır ve kolayda örnekleme yöntemi ile turist rehberlerine ulaşmak amaçlanmıştır. Bu bağlamda Türkiye Turist Rehberleri Birliği'ne ve Türkiye'deki meslek odalarına üye olan turist rehberlerine anket soruları elektronik posta yoluyla online anket olarak gönderilmiştir. Ayrıca sosyal medyadaki rehber gruplarına da iletilmiştir. Anket soruları literatürde yer alan turist rehberlerinin rolleri ve García, Gómez, Molina'nın (2011) destinasyon marka ölçeğinden yararlanılarak hazırlanmıştır. Araştırma kapsamında 82 turist rehberinden geri dönüş alınmıştır. Elde edilen verilere güvenirlik analizi ve tanımlayıcı analizler (frekans ve yüzde) uygulanarak veriler yorumlanmıştır.

Bulgular: Turist rehberlerinin yaklaşık olarak yarısı Efes'i markalaşma düzeyi en yüksek olan çekicilik olarak gördüklerini ifade ederken Pamukkale çok az rehber tarafından markalaşmış bir çekicilik olarak ifade edilmektedir. Araştırma sonuçlarına göre, rehberler tarafından çekiciliklerin markalaşmalarında en fazla katkısı olan rehber rolünün kültür ve tarih anlatımı, farkındalık oluşturma, bilgilendirme ve hikâye ve efsane anlatımı olarak görüldüğü ortaya çıkmaktadır. Tur programlarının hazırlanma süreçlerinde katkıda bulundukları görülen rehberlerin anlatımlarında markalaşma için gerekli olduğu düşünülen unsurlara yer verdikleri tespit edilmektedir. Ayrıca hem çekicilikler, hem turist davranışları hem de turlar hakkında en fazla bilgi sahibi olan rehberler, çekiciliklerin markalaşmalarının önündeki engeller hakkındaki görüşlerini bildirmişlerdir.

Atıf için (for cited); Mazan, İ. ve Özdemir, Ş. (2020). Turistik Çekiciliklerin Markalaşmalarında Turist Rehberleri Üzerine Bir Araştırma, Turist Rehberliği Dergisi, 3(1), 59-73.

* Bu çalışma Afyon Kocatepe Üniversitesi Sosyal Bilimler Enstitüsü’nde yürütülmekte olan "Yerel Çekiciliklerin Markalaşmalarında Tur Bileşenlerinin ve Turist Rehberlerinin Rolleri” başlıklı doktora tezinden üretilmiştir. 
Turist Rehberliği Dergisi (TURED) \& Yıl. 2020, Cilt. 3, Sayı. 1

Journal of Tour Guiding (JOTOG) \& Year. 2020, Volume. 3, Issue. 1

Özgünlük/Bilimsel Katkı: Alan yazında yer alan turist rehberleriyle ilgili çalışmalar incelendiğinde, turist rehberlerinin turistik çekiciliklerin markalaşmalarına katkılarını bulmaya yönelik herhangi bir araştırmaya rastlanamamıştır. Bu çalışmanın; paket turların en önemli bileşeni olan turist rehberlerinin, markalaşma sürecinde bir turistik çekiciliğe neler kattığını ortaya çıkarması yönüyle literatüre ışık tutacağ düşünülmektedir.

Çalışmanın Sınırlılıkları: Araştırmanın yapıldığı dönemde turların oldukça yoğun olması turist rehberleriyle yüz yüze görüşme imkânını azaltmıştır. Anket soruları tüm rehber odalarına e-posta yoluyla iletilmiş ve 82 adet geri dönüş alınmıştır.

Anahtar Kelimeler: Turist rehberi, destinasyon markalaşması, turistik çekicilikler.

Makale Türü: Araştırma makalesi

\begin{abstract}
Purpose and Importance: The aim of this study is to reveal the contributions of tourist guides in branding of tourist attractions. Nowadays, where branding studies of countries and cities are carried out intensively, it is possible to brand the tourist attractions. In this context, with this study, it is aimed to determine the opinions and suggestions of the tourist guides who are the leading actors of the tours, which are thought to be important in the recognition and branding of attractions. What makes this work important is to aim of the tourist guides is to identify the issues such as how they are directly or indirectly involved in the branding of attractions, whether they contribute to the touristic structuring of the attractions and their inclusion in the tours.
\end{abstract}

Methodology: The universe of the study consists of tourist guides in Turkey and it is aimed to reach tourist guide with easy sampling method. In this respect, the online survey questionnaire was sent to Turkey Tourist Guides Association (TUREB) and to the members of the chambers of tourist guiding in Turkey via e-mail. It was also sent to the guide groups on social media. The questionnaire was adapted from the roles of the tourist guides in the literature and the destination brand scale of García, Gómez, Molina (2011). Within the scope of the research, answers were received from 82 tourist guides. The data were interpreted by applying reliability analysis and descriptive analysis (percentage, frequency, arithmetic mean, standard deviation) to the obtained data.

Findings: While almost half of the tourist guides stated that they see Ephesus as the attraction with the highest branding level, Pamukkale is expressed as a branded attraction by very few guides. According to the results of the research, it is revealed that the guide role, which has the greatest contribution to the branding of the attractions by the guides, is seen as cultural and historical narration, awareness raising, informing and story and legend narration. It is determined that the guides, which are seen to have contributed to the preparation of the tour programs, use the elements thought to be necessary for branding. In addition, the guides who have the most knowledge about the attractions, the tourist behaviors and the tours have expressed their opinions about the obstacles to the branding of the attractions.

Originality/Value: When the studies related to the tourist guides in the literature are examined, no research has been found to find the contributions of the tourist guides to the branding of tourist attractions. It is thought that this study will shed light on the literature in the branding processes of the attractions in terms of revealing what tourist guides, which are the most important component of package tours.

Research Limitations/implications: The fact that the tours were intense at the time of the research decreased the opportunity to meet face-to-face with tourist guides. The survey questions were sent to all the guide rooms via e-mail, but 82 feedbacks were received.

Keywords: Tourist guide, destination branding, touristic attractions.

Paper Type: Research article 
Turist Rehberliği Dergisi (TURED) \& Yıl. 2020, Cilt. 3, Sayı. 1

Journal of Tour Guiding (JOTOG) \& Year. 2020, Volume. 3, Issue. 1

\section{Giriş}

Turistik seyahatlerin dünya üzerinde giderek artmasıyla turların her geçen gün daha fazla önem arz ettiğini söylemek mümkündür (Zillinger, Jonasson ve Adolfsson, 2012: 1). Destinasyonlara yönelik düzenlenen turlar, destinasyonların farklılaştırıcı özelliklerinin turistlere aktarılmasını sağlamaktadır. Günümüzde turizm sektöründe, destinasyonları farklılaştıran unsurların rekabet ortamında oldukça önemli bir yer aldığını söylemek mümkündür (Semone ve Kozak, 2011: 595-596). Türkiye Seyahat Acentaları Birliği'nin tanımıyla turlar; doğal, kültürel, tarihi ve turistik değerlerden en az birinin tanıtılması ve ulaşımın sağlanmasından oluşan, belirli bir fiyatla satışa sunulan, yirmi dört saatten kısa süreyi kapsayan ticari faaliyetlerdir (TÜRSAB). Ulaşım, konaklama, yeme-içme, çekicilikler ve rehberlik bileşenlerinden oluşan turlara "paket tur" denilmektedir (Hacıŏglu, 2006: 92). Seyahat acentaları ve tur operatörleri tarafindan paket turlara dahil edilen destinasyonlara bakıldığında çoğunun doğal, insan yapımı veya tarihi çekiciliklere sahip oldukları görülmektedir. $\mathrm{Bu}$ çekicilikler, destinasyonların farklılaştırıcı unsurları olarak öne çıkmaktadırlar. Bu bağlamda, özellikle turlarla ortaya çıkan bu farklı, kendine özgü çekiciliklerin markalaşmalarının, destinasyonların markalaşmalarında katkısı olduğu düşünülmektedir.

Turların bir diğer bileşeni olan rehberlik hizmeti, ülkemizde yasal olarak sadece turist rehberleri tarafindan verilebilmektedir. Turist rehberleri; sergiledikleri tavirlar ve davranışlarıyla turistlere ülke, yerel halkla ilgili ipuçları verirler ve dil, gelenekler, görenekler ile ilgili ortaya çıkabilecek olumsuz durumları engellerler (Erkol Bayram, 2019: 59). Turist rehberleri turistler arasındaki iletişimi sağlama, yerel halkla turist etkileşiminde aracılık etme, sosyalleşmeyi sağlama ve uygun davranışlar sergileyerek rol model olma gibi rollerinin ( $\mathrm{Yu}$, Weiler ve Ham, 2001: 79) yanı sira, tanıttıkları yerin algılanan imajında da önemli rol oynamaktadırlar (Huang, Hsu ve Chan, 2010: 1). Destinasyon markalaşmasının olumlu bir imaj ile mimari, yerel halk, efsaneler, kültürel değerler, kültürel miras gibi bileşenlerden yola çıkılarak oluşturulan marka kimliği ile mümkün olduğunu söylemek mümkündür (Taşcı ve Gartner, 2009: 156). Dolayısıyla turist rehberlerinin doğrudan veya dolaylı bir şekilde markalaşmaya katkıları olduğu düşünülmektedir.

Turların, çekiciliklerin deneyimlenmelerini sağladıkları ve dolayısıyla bu yerlerin yapılandırılmalarına katkı sağladıkları düşünülmektedir (Overend, 2012: 50). Bu noktada, marka olan bir çekiciliğe yönelik tur düzenlendiği gibi, tur düzenlenen bir çekiciliğin de turlar sayesinde turistik ürün olarak yapılandırılması, geliştirilmesi ve markalaşması da mümkün görülmektedir. Literatüre bakıldığında, turist rehberlerinin turistik çekiciliklerin markalaşmalarına katkılarının olup olmadığı konusunda herhangi bir çalışmaya rastlanmamıştır. Bu bağlamda, turist rehberlerinin tur programlarının oluşturulmasında ve tur operasyonları esnasında neler yaptıkları konularında bilgi ve görüşlerinin alınması, çekiciliklerin markalaşma süreçleri açısından önem arz etmektedir.

\section{Literatür İncelemesi}

\subsection{Marka ve Markalaşma}

Kapferer'e (2008) göre marka, alıcıları etkileyen isimdir ve bu etkinin kaynağ müşteriler ya da dağıtıcılar arasında zamanla kurulan ortaklıklar ve ilişkilerdir. Kotler (2005: 77), anlam ve çağrışımı olan etiketlerin her birinin marka olduğunu ifade etmektedir. Turizm açısından bakıldığında marka, etkileme gücü olan bir isimdir ve bu güç; ismin kendisi, ahengi, telaffuzu, ritmi ile değil ziyaretçilerin aklında ne anlam ifade ettiğiyle ilgilidir. Bu nedenle 


\section{IIIIII}

Turist Rehberliği Dergisi (TURED) \& Yıl. 2020, Cilt. 3, Sayı. 1

Journal of Tour Guiding (JOTOG) \& Year. 2020, Volume. 3, Issue. 1

marka, ziyaretçilerin kendiliğinden bir yerle ilişkilendirdikleri somut ve soyut, olumlu, çekici ve benzersiz değerlerin bilinen ismidir (Kapferer, 2008: 126).

Markalaşma, bir marka adı vermek ve dış dünyaya bir ürün veya hizmetin bir işletmenin damgası ile işaretlenmesinden fazlasını ifade etmektedir. Kurumsal ve uzun süreli bir katılım, yüksek seviyede kaynak ve yeterlikler gerektirmektedir (Kapferer, 2008: 31). Markalaşma her ne kadar tüketim malları alanında yaygınlaşan bir kavram olsa da, son zamanlarda hizmet deneyimlerinin, ülkelerin, şehirlerin ve bölgelerin markalaştırılmaları için uğraş verildiğini görmek mümkündür (Pearson ve Pearson, 2016: 2). MacCannell'a (1976) göre yerlerin markalayıcıları vardır. Özellikle yerlerden oluşan turistik çekiciliklerin markalaştırılmalarının ürünlerin markalaştırılmalarından çok daha zor ve karmaşık olduğu bir gerçektir.

\subsection{Turistik Çekicilikler}

Modern bir topluluğun turistik değeri sosyal, tarihi, doğal ve kültürel bileşenlerini görsel olarak bir araya toplamasına ve organize etmesine bağlıdır. Turistleri etkileyen markalaşmış yerler kendine özgü farklı çekicilikler içerirler. Çekicilikleri, kendilerinden daha az ünlü olan benzerlerinden ayırt etmek zordur. (MacCannel, 1976: 41-48). Turistik çekiciliklerin daha başarılı bir şekilde pazarlanabilmeleri için, öncelikle "çekicilik" kavramının netleştirilmesi ve çekiciliklerin ayrı olarak ele alınması gerektiğini söylemek mümkündür. Gun ve Var'a göre (2002: 42) çekicilikler; turistler için eğlence ve aktivite planlanan ve yönetilen gelişmiş yerlerdir. MacCannel (1976: 109-110) ise turistik çekicilikleri; ziyaretçilerle yerler ve markalayıcılar arasındaki ilişki olarak tanımlamaktadır. Leiper'a (1990) göre; bir yerin turistik çekicilik olarak adlandırılabilmesi için, bu yerin ziyaretçiler için özel ve olağanüstü olması ya da bir bölge veya bir milletin tipik bir özelliğini temsil ediyor olması gerekmektedir. Ritchie ve Zins (1978), her destinasyona uygulanabilecek bir destinasyon çekicilik modeli oluşturmak üzere sekiz maddelik bir özellikler sınıflandırması yapmıştır. Bu sınıflandırma; doğal güzellik ve iklim, kültürel ve sosyal özellikler, bölgenin ulaşılabilirliği, turistlere karşı davranışlar, bölgenin altyapısı, fiyat seviyeleri, spor, rekreasyon ve eğitim olanakları, alışveriş ve ticaret imkanlarından oluşmaktadır. Carter "yer" modeli ile, başarılı bir çekiciliğin fiziksel kaynaklar ve yapılandırmalar, turistler için etkinlikler ve turistlerin kattığı anlamın bir araya gelerek kesişmesiyle mümkün olduğunu anlatmaktadır. Ayrıca çekiciliğin bu üç bileşen yönünden güçlü olması gerektiğini belirtmektedir (Akt. Pearce 1991: 52).

\subsection{Turist Rehberleri ve Çekiciliklerin Markalaşmaları}

Turistlerin katıldıkları turlarda; rehberlik, hikayeler, anekdotlar, açıklamalar, gerçekler, istatistik, tarih ve bilgi içerebilecek anlatımlar gibi beklentileri olmaktadır (Overend, 2012: 50). Overend (2012: 50) turların, sönük ve sabit bir yeri yeniden canlandıramayabileceğini fakat süreklilik oluşturulmasına yardımcı olabileceğini ifade etmektedir. Bu bağlamda turların iki temel özelliğinden bahsetmektedir. Bunlardan ilkinin, tur düzenlenen yerlerin devamlı bir değişim halinde olduğu ve bu değişimde ziyaretçilerin etkili olduğunu savunmaktadır. İkincisinin ise, turların yerlerin devamlı olarak yapılandırılmalarına olanak veren süreçlerin parçası olduğunu ifade etmektedir ve dolayısıyla turların, bir yeri hem okuyup hem de o yeri yazdığını belirtmektedir.

Gržinić ve Zanketić (2008: 9-10) çekiciliklerin uzmanlıkla yönetilmeleri ve sunulan turistik ürünün kalitesinin artırılması gerektiğini belirtmektedir. Mal ve hizmetlerin amacının yeni ziyaretçilerin gelmesini ve önceki ziyaretçilerin tekrar ziyaret etmelerini sağlamak olduğunu ifade eden Gržinić ve Zanketić, bu noktada özgünlüğün ve çeşitliliğin önemini 
Turist Rehberliği Dergisi (TURED) \& Yıl. 2020, Cilt. 3, Sayı. 1

Journal of Tour Guiding (JOTOG) \& Year. 2020, Volume. 3, Issue. 1

vurgulamaktadır. Zorlu ve Erkuş (2018), çalışmalarında destinasyonların sürdürülebilirlikleri ve gelecekleri için turlardaki memnuniyetin önemli olduğunu ifade etmektedirler.

Destinasyon markalaşması ve rehberlerle ilgili çalışmalara bakıldığında, Sipahi ve Algür (2016), destinasyon marka imajına etki eden unsurları inceledikleri çalışmalarında, kaliteli turist rehberliği hizmeti destinasyonun güçlü yanı olarak belirlenmiştir. Akova (2015) ise, kentlerin markalaşma süreçlerinde turist rehberlerine yönelik yaptığı çalışmada, kent markalaşmasını turist rehberleri ile yerel yönetimler açısından incelemiş ve rehberle yerel yönetimlerin işbirliğinin yetersiz olduğu sonucuna varmış ve alınan görüşlerin uygulamaya geçirilme konusunda sorunlar olduğunu ortaya koymuştur. Literatüre bakıldığında turistik çekiciliklerin markalaşmalarını; çekiciliklerin tura dahil edilmelerinde rehberlerin katkıları, tur esnasında anlatımları, tanıtımları gibi yönlerden inceleyen bir çalışmaya rastlanmamıştır.

Arat ve Bulut (2019: 3), rehberlik hizmetinin kalitesinin turist memnuniyetini etkilediğini ve memnun olan turistin kendi ülkesinde yaptığı yorumlarla ülkenin imajına olumlu bir katkıda bulunacağını belirtmektedir. Ayrıca, memnuniyetlerinin tekrar ziyaret etme ve başkalarına önerme davranışlarına dönüşebileceğinden, tura başladıkları andan itibaren onlara refakat eden turist rehberlerinin gerekli bilgi ve donanıma sahip olarak onları en iyi şekilde ağırlamalarının oldukça önem arz ettiğini savunmaktadır ve farklılık yaratmanın önemine değinmektedir. Buradan hareketle, tur düzenlenen yerlerin tanınmalarında, benzerlerinden farklılaşmaları gerektiği ve özellikle turist rehberlerinin "hizmet kalitesi, turist memnuniyeti ve hem yerlerin hem de ülkenin imajının artırılması" gibi konuların açısından oldukça önemli rol oynadıkları sonucuna varmak mümkündür. $\mathrm{Bu}$ bağlamda turist rehberlerinin tur programları düzenlenirken turistik çekiciliklerin seçimine katkıda bulunup bulunmadıkları, turistik çekiciliklerin özelliklerini, farklılıklarını turistlere nasıl anlattıkları, nasıl bilgilendirmeler yaptıkları, sunulan ürün ve hizmetleri nasıl tanıttıkları, turist grubundan tekrar tur satın alma talepleri alıp almadıkları gibi konularda sorular sorularak; markalaşmadaki rolleri incelenmektedir.

Son zamanlarda destinasyon markalaşması konusundaki çalışmalarda marka değeri ve bileşenlerine rastlamak mümkündür. Konecknick ve Gartner (2007: 416), çalışmalarında imaj kavramının destinasyon açısından önemini vurgulamakta ve destinasyon markalarının anlaşılabilmesi için farkındalık ve bağlılık boyutlarının araştırılması gerektiğini belirtmektedirler. Taşcı ve Gartner (2009: 156) marka değerinin; bir destinasyonun yüksek bağlılık, farkındalık, algılanan kalite ve değer, güçlü marka çağrışımları ve patentler, ticari markalar gibi varlıklar elde etmesi ile oluşturulacağını ifade etmektedir. Bu bağlamda, bu çalışmada turist rehberlerine yöneltilen sorular; turistik çekiciliklerin özelliklerini ve marka değeri unsurlarını da içermektedir.

\section{Araştırmanın Amacı ve Önemi}

Bu makalenin amacı, Türkiye'de turların düzenlenebilmesi için gerekli olan rehberlik hizmetini veren turist rehberlerinin, turistik çekiciliklerin markalaşma süreçlerinde nasıl yer aldıklarını tespit etmektir. Hizmet pazarlaması kavramının soyut olma özelliği, rehberlik hizmetinin somut olarak ele alınıp katkılarının belirlenmesini zorlaştırmaktadır. Bu noktada turist rehberlerine turistik çekiciliklerle ilgili olarak markalaşma adına neler yaptıkları hakkında sorular sorularak ve konuyla ilgili fikirleri alınarak literatüre katkıda bulunmak amaçlanmıştır. 
Turist Rehberliği Dergisi (TURED) \& Yıl. 2020, Cilt. 3, Sayı. 1

Journal of Tour Guiding (JOTOG) \& Year. 2020, Volume. 3, Issue. 1

\section{Yöntem}

$\mathrm{Bu}$ çalışmada nicel yöntemlerden yararlanılmıştır. Veri toplama tekniği olarak anket tekniği tercih edilmiştir. Anket soruları literatürden yola çıkılarak hazırlanmış ve pilot çalışmada öncelikle beş turist rehberine açık uçlu sorular yöneltilerek rehberlerin görüşleri alınmıştır. Turist rehberlerinin görüşleri dikkate alınarak, bazı açık uçlu sorular kategorilendirilmiştir. Sorulardan bazıları ise, araştırmanın amacına uygun olacağı düşünülerek açık uçlu olarak bırakılmıştır. Bazı rehberlerden yüz yüze ve telefonda bilgi alınmış fakat sorular genel olarak online anket yöntemiyle rehberlere iletilmiştir. Bu sorular; turistik çekiciliklerin marka haline gelme süreçlerinde turist rehberlerinin fikirlerinin alınıp alınmadığı, turlara dahil edilmelerinde görüş bildirip bildirmedikleri, seyahat acentalarıyla bu konuda iletişim kurup kurmadıkları gibi konuların belirlenmesi ve turist rehberlerinin turistik çekiciliklerin markalaşmaları ile ilgili fikirlerinin alınmasını sağlamaya yönelik hazırlanmıştır.

Sorulardan bazıları, ilgili alan yazında yer alan turist rehberlerinin rollerinden (Weiler ve Black, 2014) yola çıkılarak hazırlanmıştır. Markalaşma ve çekicilik ile ilgili sorular ilgili literatürden ve García, Gómez, Molina'nın (2011) destinasyon marka ölçeğinden yararlanılarak hazırlanmıştır. Anket formu; yaş, cinsiyet, medeni durum, eğitim, tecrübe gibi demografik bilgilere yönelik ifadeler; üye olunan meslek odası, çalışma durumu gibi meslekle ilgili ifadeler; turistik çekiciliklerin turlara dahil edilmeleriyle ilgili ifadeler, turistik çekiciliklerin markalaştırılmaları ile ilgili ifadeler ve turist rehberlerinin markalaşmış turistik çekiciliklerle ilgili düşüncelerine yönelik ifadelerden oluşmaktadır.

Anket formu online olarak düzenlenmiş, Türkiye Turist Rehberleri Birliği'ne ve Türkiye'deki meslek odalarına e-mail yoluyla gönderilerek, elektronik ortamda bireysel olarak paylaşılarak, sosyal medyadaki rehber gruplarına iletilerek turist rehberlerine ulaştırılmıştır. Araştırmanın evrenini Türkiye'deki turist rehberleri oluşturmaktadır ve kolayda örnekleme yöntemi ile turist rehberlerine ulaşmak amaçlanmıştır. Veriler, Mayıs-Temmuz 2019 tarihleri arasında toplanmıştır. Araştırmaya katılmak isteyen 82 turist rehberinden geri dönüş alınmıştır.

\section{Bulgular}

Çalışmanın analiz sürecinde, elde edilen verilerin güvenilirlikleri teste tabi tutulmuştur. Yapılan analizler sonucunda Cronbach's Alpha kat sayısı ile güvenirlik 0,908 olarak tespit edilmiştir. $\mathrm{Bu}$ sonuç, 0,70'in üzerindedir ve ölçeğin güvenirliğinin yüksek olduğunu göstermektedir. Turist rehberlerinden elde edilen veriler doğrultusunda yaş, cinsiyet, medeni durum, tecrübe ile ilgili analizler aşağıdaki tabloda verilmiştir.

Araştırmaya katılan turist rehberlerinin demografik özelliklerini yansıtan Tablo 1'de turist rehberlerinin \%34,1'inin kadın, \%65,9'unun erkek olduğu; \%32,9'unun bekar, $\% 67,1$ 'inin evli olduğu görülmektedir. Katılımcıların yaşlarıyla ilgili cevaplar ele alındığında, en fazla kişinin 30-39 ve 50-59 yaş aralığında bulundukları anlaşılmaktadır. Bu tabloda, katılımciların \%48,8'i lisans mezunu ve onu takiben $\% 31,7$ 'sinin yüksek lisans, \%8,5'inin doktora mezunu olduğu görülmektedir. Mesleki tecrübe konusuna bakıldığında \%46,3'lük bir grubun 16 yıl ve üzeri tecrübeye sahip olduğu görülmektedir. Araştırmaya katılanların $\% 92,7$ 'si eylemli olarak görev yapmaktadır. 
Turist Rehberliği Dergisi (TURED) \& Yıl. 2020, Cilt. 3, Sayı. 1

Journal of Tour Guiding (JOTOG) \& Year. 2020, Volume. 3, Issue. 1

Tablo 1: Katılımcıların Demografik ve Meslekle İlgili Özellikleri

\begin{tabular}{|c|c|c|c|c|c|c|c|}
\hline Değişken & Grup & $\mathbf{n}$ & $\%$ & Değişken & Grup & $\mathbf{n}$ & $\%$ \\
\hline \multirow{2}{*}{ Cinsiyet } & Kadın & 28 & 34,1 & \multirow{4}{*}{ Tecrübe } & $1-5$ y1l & 20 & 24,4 \\
\hline & Erkek & 54 & 65,9 & & $6-10$ y1l & 11 & 13,4 \\
\hline \multirow{5}{*}{$\begin{array}{l}\text { Yaş } \\
\text { grubu }\end{array}$} & $20-29$ yaş & 14 & 17,1 & & $11-15$ y1l & 13 & 15,9 \\
\hline & $30-39$ yaş & 29 & 35,4 & & 16 yıl ve üzeri & 38 & 46,3 \\
\hline & $40-49$ yaş & 10 & 12,2 & \multirow{4}{*}{$\begin{array}{l}\text { Çalışma } \\
\text { durumu }\end{array}$} & Eylemli turist rehberi & 76 & 92,7 \\
\hline & $50-59$ yaş & 20 & 24,4 & & $\begin{array}{l}\text { Eylemsiz turist } \\
\text { rehberi }\end{array}$ & 5 & 6,1 \\
\hline & 60 yaş ve üzeri & 9 & 11,0 & & Diğer (akademisyen & 1 & 1,2 \\
\hline \multirow{2}{*}{$\begin{array}{l}\text { Medeni } \\
\text { durum }\end{array}$} & Bekâr & 27 & 32,9 & & turist rehberi) & & \\
\hline & Evli & 55 & 67,1 & \multirow{9}{*}{$\begin{array}{l}\text { Bağlı } \\
\text { bulunulan } \\
\text { rehber } \\
\text { odası }\end{array}$} & ANRO & 3 & 3,7 \\
\hline \multirow{4}{*}{$\begin{array}{l}\text { Eğitim } \\
\text { durumu }\end{array}$} & Ön lisans & 9 & 11,0 & & ARO & 4 & 4,9 \\
\hline & Lisans & 40 & 48,8 & & BURO & 4 & 4,9 \\
\hline & Yüksek lisans & 26 & 31,7 & & ÇARO & 9 & 11,0 \\
\hline & Doktora & 7 & 8,5 & & İंRO & 32 & 39,0 \\
\hline & & & & & İZRO & 26 & 31,7 \\
\hline & & & & & TRO & 1 & 1,2 \\
\hline & & & & & MURO & 2 & 2,4 \\
\hline & & & & & SURO & 1 & 1,2 \\
\hline
\end{tabular}

Katılımcılara Türkiye'de en fazla markalaşmış çekiciliğin hangisi olduğu ile ilgili bir soru yöneltilmiştir. Pilot çalışmada turist rehberlerine bu soru açık uçlu olarak yöneltilmiş ve görüşleri alınmıştır. Ayrıca Kültür Varlıkları ve Müzeler Genel Müdürlüğü'nün verilerine göre en çok ziyaret edilen müze ve ören yerleri incelenmiştir. Bu bağlamda "Efes, Kapadokya, Pamukkale, Sultanahmet, Truva" çekicilikleri bu sorunun kategorileri olarak belirlenmiştir. Daha sonra katılımcılara, bunların dışındaki çekicilikleri belirtebilmeleri için "diğer" seçeneği sunulmuştur. Katılımcıların yanıtlarına Tablo 2'de yer verilmektedir.

Tablo 2: Katılımcıların Markalaşma Düzeyi En Yüksek Olan Çekicilikle İlgili Görüşleri

\begin{tabular}{|l|c|c|}
\hline & Sayı & Yüzde \\
\hline Efes & 44 & 53,7 \\
\hline Kapadokya & 18 & 22,0 \\
\hline Pamukkale & 3 & 3,7 \\
\hline Sultanahmet & 8 & 9,8 \\
\hline Truva & 6 & 7,3 \\
\hline Diğger & 3 & 3,7 \\
\hline
\end{tabular}

Katılımcıların Türkiye'de markalaşma düzeyi en yüksek olan çekiciliğin hangisi olduğuna dair soruya verdikleri cevapların dağılımı Tablo 2'de verilmiştir. Türkiye'de markalaşma düzeyi en yüksek olan çekicilik hakkındaki görüşleri sorulmuştur. Katılımcıların \%53,7'sinin bu soruya Efes cevabı verdiği görülürken, \%22'sinin Kapadokya cevabını verdiği ve sirasıyla Sultanahmet, Truva, Pamukkale ve diğer yerlerin bu çekicilikleri takip ettiği görülmektedir. "Diğer" seçeneğinde üç katılımc1 "Antalya", "Aspendos - Perge - Side" ve "hepsi" cevaplarını vermişlerdir. Bu cevapların nedenlerini 10. soruda açıklayan katılımcılar; en fazla "benzersiz", "farklı", "eşsiz", "doğal güzellik", "görsel çekicilik", "sıra dışı olma" gibi farklılaştırıcı özelliklerinden dolayı ve "reklam, tanıtım çalışmalarının fazla oluşu", "ünlü olması", "kalite sunması", "hemen akla gelmesi”, "her yerde fotoğraflarının paylaşılması" gibi pazarlama ve markalaşma ile ilgili özelliklerinden ötürü bu çekiciliklerin marka olduğunu düşündüklerini belirten yorumlara yer vermişlerdir. 
Turist Rehberliği Dergisi (TURED) \& Yıl. 2020, Cilt. 3, Sayı. 1

Journal of Tour Guiding (JOTOG) \& Year. 2020, Volume. 3, Issue. 1

Bulguların değerlendirilmesi sürecinde, markalaşmış çekicilik hakkındaki görüşlerinden sonra katılımcılara çekiciliklerin markalaşmalarında rehberlerin rolleri hakkındaki görüşleri sorulduğunda alınan yanıtlar Tablo 3 'te verilmiştir.

Tablo 3: Katılımcıların Markalaşmada Turist Rehberlerinin Rolleri ile İlgili Görüşleri

\begin{tabular}{|c|c|c|c|c|}
\hline & \multicolumn{2}{|c|}{$\begin{array}{l}\text { Turist Rehberlerinin } \\
\text { Markalaşmada Rolleri }\end{array}$} & \multirow{2}{*}{$\begin{array}{l}\text { Bütün } \\
\text { içinde }\end{array}$} & \multirow[t]{2}{*}{$\mathbf{N}$} \\
\hline & Sayı & $\%$ & & \\
\hline Kültür ve tarih anlatımı & 56 & 68,29 & 18,92 & 82 \\
\hline Farkındalık oluşturma & 48 & 58,54 & 16,22 & 82 \\
\hline Bilgilendirme & 45 & 54,88 & 15,20 & 82 \\
\hline Hikaye ve efsane aktarımı & 36 & 43,90 & 12,16 & 82 \\
\hline Yerel halkla turist etkileşimi & 32 & 39,02 & 10,81 & 82 \\
\hline Güzel anılar oluşturma & 29 & 35,37 & 9,80 & 82 \\
\hline Yerel ürün tanıtımı & 27 & 32,93 & 9,12 & 82 \\
\hline Yol göstericilik & 23 & 28,05 & 7,77 & 82 \\
\hline & 296 & & 100,00 & \\
\hline
\end{tabular}

Tablo 3'teki ilk iki sütunda "turist rehberlerinin hangi yönüyle markalaşmada etkili olduklarına" yönelik ölçmenin sonuçları yer almaktadır. 82 katılımcıya yöneltilen soruda seçeneklerin birden fazlasını işaretlemek mümkündür. Bundan dolayı sayı 82 'den büyüktür ve oranların toplamı da 1'den büyüktür. Verilen cevaplara göre turist rehberlerinin "kültür tarih anlatımı" suretiyle markalaşmaya katkıda bulunmakta olduğunu ifade eden katılımcıların sayıs 56 'dır. Bunların toplam katılımcılara oranı ise \%68,29'dur. "Kültür ve tarih anlatımı" rolü tüm cevaplar içinde en çok seçilen roldür. Bundan sonra da "farkındalık oluşturmak" rolü gelmektedir. Rollerin büyüklüğ̈̈ ve önemi hakkında daha somut yorum yapabilmek amaciyla cevapların tamamı 100 kabul edildiğinde her bir rolün toplam içinde oranı bulunmuş ve bu oranlar üçüncü sütunda verilmiştir. Marka olmanın "benzerler arasında farklı olmak ve bu farklılığın gerçek bir farklılık olması gerektiği” hatırlanırsa, turist rehberleri hem çekiciliğin gerçek anlamda anlaşılmasını sağlayarak hem de benzerlerinden farklılıklarını vurgulayarak markalaşmaya katkı sunmaktadır. Markalaşmada rehberlerin rolünün analiz edildiği Tablo 3'teki verilere göre, katılımcılar turist rehberlerinin, çekiciliklerin markalaşmalarında en fazla katkıyı kültür ve tarih anlatımı ile sağladıklarını belirtmektedirler ve bu ifade seçilen ifadelerin içinde \%18,92 ile en yüksek orana sahiptir. Bu ifadeyi sırasıyla farkındalık oluşturma, bilgilendirme, hikaye ve efsane aktarımı, yerel halkla turist etkileşimi, güzel anılar oluşturma, yerel ürün tanıtımı rolleri takip etmektedir. Literatürde çekiciliklerin farklılaştırıcı özelliklerinin markalaşmada önemli olduğu ve bu farklılaştırıcı özelliklerin kültür, tarih, hikâyeler, efsaneler ve yer ile ilgili bilgiler gibi unsurlar olduğu belirtildiğinden, sonuçların literatürle uyumlu olduğu söylenebilir. Yol göstericilik rolü ise $\% 7,77$ ile en düşük orana sahiptir. Turist rehberlerinin "yol gösterici" rolü olmazsa olmaz bir özellik olmasına karşın, turist rehberlerinden beklenen işlevler içinde turistik çekiciliğin markalaşmasına en az katkıda bulunan işlev olarak ortaya çıkmıştır.

Araştırmada katılımcıların tur programının hazırlanma sürecinde katkıda bulunup bulunmadıklarının dağılımı Tablo 4'te incelenmiştir. Katılımcıların aynı tur programında birden fazla konuda katkıda bulunmaları mümkün olduğu için tek soruda çok sayıda cevap verebilmeleri sağlanmıştır. İlk iki sütundaki rakamların toplamının katılımcı sayısından büyük olmasının nedeni tek soruya verilmiş birden fazla cevaptır. 
Turist Rehberliği Dergisi (TURED) \& Yıl. 2020, Cilt. 3, Sayı. 1

Journal of Tour Guiding (JOTOG) \& Year. 2020, Volume. 3, Issue. 1

Tablo 4: Katılımcıların Tur Programının Hazırlanma Sürecinde Katkıları

\begin{tabular}{|c|c|c|c|c|}
\hline & \multicolumn{2}{|c|}{ Tur programına katkı } & \multirow{2}{*}{ Bütün içinde } & \multirow{2}{*}{$\mathbf{N}$} \\
\hline & Sayı & $\%$ & & \\
\hline Çekiciliği tura dâhil etme & 56 & 68,29 & 22,58 & 82 \\
\hline İşletme tavsiyesi & 45 & 54,88 & 18,15 & 82 \\
\hline Turist istek ve şikâyetlerinin bildirilmesi & 45 & 54,88 & 18,15 & 82 \\
\hline Tur güzergâh1 belirlenmesi & 30 & 36,59 & 12,10 & 82 \\
\hline Aktivite önerisi & 29 & 35,37 & 11,69 & 82 \\
\hline Diğer & 43 & 52,44 & 17,34 & 82 \\
\hline & 248 & & 100,00 & \\
\hline
\end{tabular}

Katılımcilar seyahat acentaları tarafindan hazırlanan tur programlarının hazırlanma süreçlerinde turist rehberlerine nasıl katkıda bulundukları sorulduğunda, Tablo 4'te en fazla katkıda bulundukları konunun çekiciliğin tura dâhil edilmesi olduğunu belirttikleri görülmektedir ve bu rol seçilen ifadeler arasında \%22,58 ile en fazla orana sahiptir. Turist rehberleri, turistlerle yüz yüze ilişki kurmanın getirdiği bilgi avantaj1 ile turistin ilgisini çekebilecek, destinasyon içinde hangi unsurların ön plana çıkartılabileceği konusunda söz sahibi olmaktadır. Pazarlama literatüründe ürünün esas faydasını sağlayan kısmına öz ürün adı verilmektedir. Öz ürünü marka ambalaj, tasarım ile somutlaştırılmakta ve montaj, satış sırası ve sonrası servis, garanti gibi özelliklerle zenginleştirilmektedir. Turist rehberleri, sunulacak ürünün tasarımında ve sunulmasına rol alarak "öz ürün" olan turistik çekiciliği, marka haline getirmekte yani "zenginleştirilmiş veya genişletilmiş ürün" haline getirmektedir. Genişletilmiş ürünlerin benzer başka ürünlerden farklılıklarını vurgulayabilecek özelliklerinin varlı̆g ise o ürünün markalaşmasına katkıda bulunmaktadır. Turist rehberleri; işletme tavsiyesi, turist istek ve şikâyetlerinin bildirilmesi, tur güzergâhının belirlenmesi ve en az aktivite önerisinde bulunma konularında katkıda bulunarak ürünün daha geniş olarak sunulmasına yardımcı olmaktadır. Aktivite önerisinde bulunma ifadesi seçilen ifadeler arasında \%11,69'luk bir dilimdedir. Ayrıca katkıda bulunma şanslarının olmadıklarını, çünkü kendilerine görüș sorulmadığını belirtenler ve bazı hataları ve yanlışlıkları seyahat acentalarına bildirdiklerini söyleyenler de mevcuttur.

Katılımcıların, çekiciliklerin markalaşma sürecinde yer alan farklılaşma ve hatırlanma unsurlarıyla ilgili olarak rehberlerin katkıları ile ilgili görüşleri Tablo 5'te incelenmektedir. Daha önceki tablolarda olduğu gibi tek soruda çok sayıda cevap verebilmeleri nedeniyle ilk iki sütundaki rakamların toplamı katılımcı sayısından büyüktür. Katılımcıların; turist rehberlerinin bir çekiciliğin farklılaşması ve hatırlanmasında en fazla rol oynayan performanslarının kültür ve tarih anlatımı olduğu ve bunu hikâye ve efsane anlatımıyla bilgilendirmenin takip ettiğini belirttikleri Tablo 5'te, kültür ve tarih anlatımının oranı seçilen ifadelerin \%17,28'i olarak görülmektedir. Tabloya bakıldığında bu konuda en az katkısı olan rollerinin ise yol göstericilik olduğunu düşündükleri anlaşılmaktadır ve seçilen ifadeler arasında \% 7,31'lik bir paya sahiptir. Ürünlerin marka olarak konumlandırılmasında kullanılan unsurlardan bir tanesinin ürünlere ait öyküler ve efsaneler olduğu bilinmektedir. Turistik çekicilikleri ziyaret eden turistlerin aktiviteleri bir tür katılımlı belgeseldir. Tarihi arka planı öğrenilen turistik çekicilikler, benzerlerinden ayrışmakta ve daha kalıcı olabilmekte, başka bir ifade ile marka haline gelmektedir. Bu bakımdan turistik çekiciliklerle ilgili kültür, tarih, efsane anlatımlarıyla sağlanan etkileşim ve farkındalık yoluyla turist rehberleri turistik çekiciliklere markalaşma katkısı sağlamaktadır. 
Turist Rehberliği Dergisi (TURED) \& Yıl. 2020, Cilt. 3, Sayı. 1

Journal of Tour Guiding (JOTOG) \& Year. 2020, Volume. 3, Issue. 1

Tablo 5: Katılımcıların Turistik Çekiciliklerin Farklılaşmaları ve Hatırlanmalarında Turist Rehberlerinin Rolleri İle İlgili Görüşleri

\begin{tabular}{|l|c|c|c|c|}
\hline \multirow{2}{*}{} & \multicolumn{2}{|c|}{$\begin{array}{c}\text { Farklılaşma ve hatırlanmada } \\
\text { rol }\end{array}$} & \multirow{2}{*}{ Bütün içinde } & \multirow{2}{*}{ N } \\
\cline { 2 - 3 } & Sayı & \% & & \\
\hline Kültür ve tarih anlatımı & 52 & 52,44 & 17,28 & 82 \\
\hline Hikâye ve efsane aktarımı & 43 & 45,12 & 14,29 & 82 \\
\hline Bilgilendirme & 43 & 52,44 & 14,29 & 82 \\
\hline Yerel halkla turist etkileşimi & 36 & 43,90 & 11,96 & 82 \\
\hline Farkındalık oluşturma & 39 & 63,41 & 12,96 & 82 \\
\hline Yerel ürün tanitımı & 37 & 26,83 & 12,29 & 82 \\
\hline Güzel anılar oluşturma & 29 & 47,56 & 9,63 & 82 \\
\hline Yol göstericilik & 22 & 26,83 & 7,31 & 82 \\
\hline & $\mathbf{3 0 1}$ & & $\mathbf{1 0 0 , 0 0}$ & \\
\hline
\end{tabular}

Çekiciliklerin markalaşma sürecinde kalite, imaj oluşturma ve tavsiye edilme unsurlarına rehberlerin katkısının araştırıldığı Tablo 6'da rehberlerin görüşleri yer almaktadır.

Tablo 6: Katılımcıların Turistik Çekiciliklerin Kalite, İmaj ve Tavsiye Edilme Konularında Turist Rehberlerinin Rollerinin Katkısına İlişkin Görüşleri

\begin{tabular}{|l|c|c|c|c|}
\hline \multirow{2}{*}{} & \multicolumn{2}{|c|}{ Kalite, imaj ve tavsiyede rol } & \multirow{2}{*}{ Bütün içinde } & \multirow{2}{*}{ N } \\
\cline { 2 - 3 } & Say1 & $\%$ & 15,06 & 82 \\
\hline Kültür ve tarih anlatımı & 47 & 57,32 & 14,42 & 82 \\
\hline Bilgilendirme & 45 & 54,88 & 14,42 & 82 \\
\hline Farkındalık oluşturma & 45 & 54,88 & 13,14 & 82 \\
\hline Yerel ürün tanıtım1 & 41 & 50,00 & 12,82 & 82 \\
\hline Yerel halkla turist etkileşimi & 40 & 48,78 & 11,54 & 82 \\
\hline Hikaye ve efsane aktarım1 & 36 & 43,90 & 10,26 & 82 \\
\hline Yol göstericilik & 32 & 39,02 & 8,33 & 82 \\
\hline Güzel anılar oluşturma & 26 & 31,71 & $\mathbf{1 0 0 , 0 0}$ & \\
\hline & $\mathbf{3 1 2}$ & & & \\
\hline
\end{tabular}

Sorulan soruya katılımcıların birden fazla cevap verebilmeleri nedeniyle Tablo 6'da yer alan ilk iki sütundaki rakamların toplamı katılımcı sayısından büyüktür. Turistik çekiciliklerin kalite sunma, imaj oluşturma ve tavsiye edilme konularında rehberlerin rollerinin incelendiği Tablo 6'da \%15,06 ile en fazla kültür ve tarih anlatımının daha sonra farkındalık oluşturmanın ve bilgilendirme rollerinin katkısı olduğunu düşündükleri görülmektedir. Bu rolleri yerel ürün tanıtımı ve hikaye ve efsane anlatımı takip etmektedir. Tabloya göre rehberlerin çoğunluğu güzel anılar oluşturma rollerinin çekiciliğin kalite, imaj ve tavsiye edilme konularına diğerlerine kıyasla daha az katkı sağladığı görülmektedir. Turist rehberlerinin yol göstericilik rolünün de düşük olması $(\% 8,33)$ turistik çekiciliğin kalitesinden, imajından ayrı düşünüldüğü görülmektedir. Tablo bütün olarak değerlendirildiğinde rehberlerin bilgilendirmede ve kültür ve tarih anlatımında önemli olduğu ancak turistik çekicilikle bütünleştirilmediği ayrı düşünüldüğü anlamına gelmektedir. Bunun nedenleri ve sonuçları ayrı bir araştırma konusu olabilecek kadar farklı konudur.

Araştırmada rehberlerin markalaşma sürecinde yer alan yerel unsurlara anlatımlarında yer verme durumlarının sorulduğu soruya verdikleri cevaplar Tablo 7'de yer almaktadır. 
Turist Rehberliği Dergisi (TURED) \& Yıl. 2020, Cilt. 3, Sayı. 1

Journal of Tour Guiding (JOTOG) \& Year. 2020, Volume. 3, Issue. 1

Tablo 7: Katılımcıların Anlatımlarında ve Yorumlarında Yerel Unsurlara Yer Verme Durumlar1

\begin{tabular}{|l|c|c|c|c|}
\hline & \multicolumn{2}{|c|}{ Yerel Unsurlara Yer Verme } & Bütün & \multirow{2}{*}{ N } \\
\cline { 2 - 3 } & Sayinde & \% & \\
\hline Çekiciliğin tarih ve kültürünü yorumlama & 66 & 46,34 & 23,74 & 82 \\
\hline Efsane ve hikaye anlatımı & 60 & 73,17 & 21,58 & 82 \\
\hline $\begin{array}{l}\text { Çekiciliğin adını, sembolünü, sloganını } \\
\text { anlatma }\end{array}$ & 58 & 70,73 & 20,86 & 82 \\
\hline Çekiciliğin benzersiz özelliklerini anlatma & 56 & 68,29 & 20,14 & 82 \\
\hline Yerel ürünleri tanıtma & 38 & 36,59 & 13,67 & 82 \\
\hline & $\mathbf{2 7 8}$ & & $\mathbf{1 0 0 , 0 0}$ & \\
\hline
\end{tabular}

Sorulan soruya katılımciların birden fazla cevap verebilmeleri nedeniyle Tablo 7'de yer alan ilk iki sütundaki rakamların toplamı katılımcı sayısından büyüktür. Tablo 7'den turist rehberlerinin anlatım ve yorumlarında en fazla çekiciliğin tarih ve kültürünü yorumlamaya yer verdikleri anlaşılmaktadır. Her ne kadar Tablo 6 'da katılımcıların yarısından fazlasının efsane ve hikaye anlatma rollerinin kalite, imaj ve tavsiye edilmede katkısı olmadığını düşündükleri görülse de, Tablo 7'de rehberlerin büyük çoğunluğunun turlarda efsane ve hikaye anlatımına yer verdikleri görülmektedir. Bu ifade seçilenler arasında \%23,74 ile en yüksek oran olarak görülmektedir. $\mathrm{Bu}$ unsurun haricinde anlatım ve yorumlarında sırasıyla çekiciliğin adını, sembol ve sloganını anlatmaya, benzersiz özelliklerini anlatmaya yer verdikleri görülmektedir. Ayrıca tabloda katılımcıların yaklaşık üçte ikisinin yerel ürünlerin tanıtımına yer vermedikleri görülmektedir ve bu ifade seçilenler içinde $\% 13,67^{\prime}$ lik bir paya sahip olarak görülmektedir. Turistik çekiciliklerin benzerlerinden farklılaşması için turistik çekiciliğe taklit edilemez bir özellik katmak onu kendi kategorisinde eşsiz hale getirecektir. Pamukkale'yi, Efes'i, Kapadokya'yı, Truva'yı ve Sultanahmet'i yerel unsurlarla desteklemek onlar1 rakipsiz birer ürün haline getirmekte ve dolayısıyla çok değerli bir marka haline getirmektedir. Bunu yapmanın yollarından birisi turistik çekicilikle ilgili yerel unsurlara yer vermektedir.

Türkiye'deki turistik çekiciliklerin markalaşmalarının önündeki engellerle ilgi katılımcı görüşleri Tablo 8'de verilmektedir.

Tablo 8: Katılımcıların Türkiye'deki Turistik Çekiciliklerin Markalaşmalarındaki Engeller Hakkındaki Görüșleri

\begin{tabular}{|c|c|c|c|c|}
\hline & \multicolumn{2}{|c|}{$\begin{array}{c}\text { Yerel çekiciliklerin } \\
\text { markalaşmasında engeller }\end{array}$} & \multirow{2}{*}{$\begin{array}{l}\text { Yüzde } \\
\text { içinde }\end{array}$} & \multirow[t]{2}{*}{$\mathbf{N}$} \\
\hline & Say1 & $\%$ & & \\
\hline Tanıtım yetersizliği & 50 & 60,98 & 15,92 & 82 \\
\hline Tur programı problemleri & 40 & 48,78 & 12,74 & 82 \\
\hline Konaklama işletmelerinin kalite düşüklüğü & 34 & 41,46 & 10,83 & 82 \\
\hline Tur şirketinin hizmet kalitesinin düşük olması & 32 & 39,02 & 10,19 & 82 \\
\hline Yiyecek-içecek işletmelerinin kalite düşüklüğü & 29 & 35,37 & 9,24 & 82 \\
\hline Ürün ve hizmet yetersizliği & 25 & 30,49 & 7,96 & 82 \\
\hline Aktivite yetersizliği & 25 & 30,48 & 7,96 & 82 \\
\hline Çevre kirliliği & 23 & 28,05 & 7,32 & 82 \\
\hline Anlayışsız ve memnuniyetsiz turist & 16 & 19,51 & 5,10 & 82 \\
\hline Ulaştırma işletmelerinin kalite düşüklüğü & 16 & 19,51 & 5,10 & 82 \\
\hline Rehberlerin performans düşüklüğü & 6 & 7,32 & 1,91 & 82 \\
\hline Diğer & 18 & 21,95 & 5,73 & 82 \\
\hline & 314 & & 100,00 & \\
\hline
\end{tabular}


Turist Rehberliği Dergisi (TURED) \& Yıl. 2020, Cilt. 3, Sayı. 1

Journal of Tour Guiding (JOTOG) \& Year. 2020, Volume. 3, Issue. 1

Sorulan soruya katılımciların birden fazla cevap verebilmeleri nedeniyle Tablo 8'de yer alan ilk iki sütundaki rakamların toplamı katılımcı sayısından büyüktür. Bu soruyla turizm sektörünün içinde yer alan rehberlerin gözüyle turistik çekiciliklerin marka olmasının önündeki engeller tespit edilmiştir. Katılımcıların Türkiye'deki turistik çekiciliklerin markalaşmasının önündeki engellerle ilgili görüşlerinin yer aldığı Tablo 8'de en fazla tanıtım yetersizliğini seçtikleri görülmektedir. $\mathrm{Bu}$ unsuru sırasıyla tur programı problemleri, konaklama işletmelerinin, tur şirketlerinin, yiyecek-içecek işletmelerinin hizmet kalitesi düşüklüğü, ürün ve hizmet yetersizliği, aktivite yetersizliği, çevre kirliliği unsurları takip etmektedir. Katılımcıların en az seçtikleri engellerin ise turist rehberlerinin performans düşüklügüü, ulaştırma işletmelerinin hizmet kalitesi düşüklügü ve anlayışsız turistler unsurları olduğu görülmektedir. En fazla seçilen ifade olan tanıtım yetersizliği ifadesi seçilenlerin $\% 15,92$ 'sini oluştururken, en az seçilen rehberlerin performans düşüklüğü ifadesi \%1,91 oranındadır. Marka olmak tesadüflere bağlı değildir. Marka olmak, organize olmuş, istikrarlı pazarlama çalışmaları (tanıtım) ile mümkündür. Bu tablo göstermektedir ki bir turistik çekiciliğin marka haline gelmesi için problemsiz tur programları, kaliteli konaklama, seyahat ve yiyecek içeceklerinin varlığı gerekmektedir. Bir ürünün ismini medya imkânlarıyla duyurmak mümkündür. Ancak kalıcı olması için kaliteli ve nitelikli olması gerekmektedir.

Katılımcıların günümüzde çekiciliklerin markalaşmalarında önemli yeri olduğu düşünülen sosyal medya ve internette paylaşım yapma durumları ve turistlerden Türkiye'de başka bir bölgeye tur talebi alma durumları Tablo 9'da görülmektedir.

Tablo 9: Katılımcıların Sosyal Medyada Turla İlgili Paylaşım Yapma ve Tekrar Tur Talebi Alma Durumları

\begin{tabular}{|l|c|c|c|c|}
\hline & \multicolumn{2}{|c|}{ Evet } & \multicolumn{2}{|c|}{ Hayır } \\
\cline { 2 - 5 } & Sayı & $\%$ & Say1 & $\%$ \\
\hline $\begin{array}{l}\text { Sosyal medyada ve/veya internette turlar ve gezilen yerlerle ilgili } \\
\text { fotoğraf ve bilgi paylaşırım }\end{array}$ & 60 & 73,17 & 22 & 26,83 \\
\hline Turdan sonra turistlerden başka bir bölge için tur talebi alıyorum & 79 & 96,34 & 3 & 3,66 \\
\hline
\end{tabular}

Ürünlerin tüketiciler arasında tanınırlığını artıran sosyal medya paylaşımları ve tavsiye etmeler de turistik çekiciliklerin marka olarak konumlandırılmasına katkı sağlamaktadır. Tur organizasyonundan veya rehberden elde edilen memnuniyet de tekrar ziyaret etme veya tura katılma niyetini artırmaktadır. Katılımciların sosyal medya veya internette turlarla ilgili paylaşım yapıp yapmadıklarının incelendiği Tablo 9'da rehberlerin $\% 73,17$ 'sini paylaşım yaptığı, \%26,83'ünün paylaşım yapmadığı görülmektedir. Ayrıca, \%96,34'ünün turdan sonra başka bir bölge için tur talebi aldığ tabloda yer almaktadır. Tekrar satın alma niyetinin yüksekliği ve sosyal medya paylaşımları turistik çekiciliklerin marka olmasında güçlü bir alternatif olarak görülmektedir.

\section{Sonuç, Tartışma ve Öneriler}

Seyahat acentaları tarafından seçilip bir araya getirilen kendilerine has özellikleri olan turistik çekicilikler, paket turlarda turistlere sunulmaktadır. Böylece, bu turistik çekiciliklerin turistler tarafından görülüp deneyimlenmeleri sağlanmaktadır. Mesleki bilgi, deneyim ve tecrübeler açısından donanımlı, çekicilikler hakkında oldukça fazla bilgi sahibi olan hatta bazı çekiciliklerin bulunduğu yerlerde uzmanlaşarak bilgilerini daha da artıran turist rehberleri, bu çekicilikleri tanıtmakla görevlidir. Aynı zamanda rehberler; turistlerin çekicilikleri deneyimlerken nelerden hoşlandıkları nelerden hoşlanmadıkları, nelerden etkilendikleri veya nelerden şikâyetçi oldukları gibi birçok konuda gözlem yapabilmektedirler. Bu noktada, çekiciliklerin markalaşma süreçlerinde hem doğrudan veya dolaylı olarak katkıları 


\section{IIIIII}

Turist Rehberliği Dergisi (TURED) \& Yıl. 2020, Cilt. 3, Sayı. 1

Journal of Tour Guiding (JOTOG) \& Year. 2020, Volume. 3, Issue. 1

bulundukları hem de aktif bir şekilde yer almalarının gerektiği düşünülmektedir. Bu bağlamda, çekiciliklerin markalaşmaları konusunda rehberlerin hem görüşleri alınmış hem de tur operasyonlarındaki rolleri ve performanslarıyla nasıl katkıda bulundukları incelenmiştir.

$\mathrm{Bu}$ araştırmada, turist rehberlerinin markalaşma düzeyi en yüksek çekicilik olarak çoğunlukla Efes'i ve daha sonra Kapadokya'yı gördüklerini belirtmeleri, çok azının Pamukkale'yi belirtmeleri Türkiye'deki destinasyon ve şehir markalaşması çalışmaları açısından ayrıca ele alınması gereken bir konu olarak ortaya çıkmaktadır. Turist rehberleri, öz ürün olarak değerlendirilebilecek destinasyonlara, sunulacak hizmetlerin tasarımında ve sunulmasina rol alarak yeni boyutlar eklemekte veya yeni konsept olarak sunarak zenginleştirmektedir. Tüm bunlar ise tüketicilerin zihninde konumlandırmaya yönelik yeni imkânlar sunmaktadır. Rehberlere göre "eşsiz olma" ve "pazarlama - tanıtım" unsurları ön plana çıkmaktadır.

Rehberlerin yarısından fazlasının "çekiciliğin tarih ve kültürünü yorumlama, efsane ve hikaye anlatımı, çekiciliğin adını-sembolünü- sloganını anlatma, çekiciliğin benzersiz özelliklerini anlatma" unsurlarına anlatımlarında yer verdikleri görülmektedir. Ürünlerin marka olarak konumlandırılmasında kullanılan unsurlardan bir tanesinin ürünlere ait öyküler ve efsaneler olduğundan hareketle turistik çekiciliklerin eşsiz hale gelmesinde ve rehberlerin önemli bir yerinin olduğunu söylemek mümkündür. Rehberler turistik çekiciliklerin eşsiz hale gelmesinde ve taklit edilemez hale gelmesinde kültür ve tarih anlatmakta ancak yerel ürün tanıtımlarına yeteri kadar vermemektedir. Bunun nedeni olarak ise "Yerel ürün tanıtımının, yerli halk ile turist etkileşimi sağlamanın ve güzel anılar oluşturmanın" markalaşma konusuna daha az katkıda bulunduğunu düşünmeleri olarak tespit edilmiştir.

Turist rehberleri; rehberlerin bilgilendirme, kültür ve tarih anlatımında önemli olduğunu düşünmektedirler. $\mathrm{Bu}$ bakımdan rehberler kendilerini turistik çekiciliklerin markalaşmasında önemli görmektedirler. Markalaşmada, yol göstericilik rolünün de düşük olduğunun düşünülmesi rehberlerin bütüncül bir yaklaşıma sahip olduğunu, turistik çekiciliklerin ve turların tasarımından organizasyonuna kadar birçok konuda düşüncelerinin olduğunu göstermektedir.

Bir ürünün marka olması belirli bir strateji ile istikrarlı çalışma ile elde edilebilir. Bu çalışma göstermektedir ki turistik çekiciliğin marka haline gelmesi için problemsiz tur programları, kaliteli konaklama, seyahat ve yiyecek içeceklerinin varlığı gerekmektedir. Bir ürünün ismini kısa sürede medya imkânlarıyla duyurmak mümkündür. Markalaşmanın sağlanabilmesi için rehberlerin sunacağı hizmetlerin tamamının kaliteli ve nitelikli olması gerekmektedir.

Turistik çekiciliklerin, potansiyel turistler arasında yayılmasını ve ünlenmesi sağlayan dikkat çekici sosyal medya paylaşımları da turistik çekiciliklerin marka olmasına katkı sağlamaktadır. Ayrıca tur organizasyonundan veya rehberden elde edilen memnuniyet de turistik çekicilik hakkında olumlu mesajların yayılmasına vesile olacağ 1 varsayılabilir. Doğrudan söylemek gerekirse sosyal medya paylaşımında bulunmayı getirebilecek alternatifler sunma ve sunulan rehberlik hizmeti ile sağlanacak memnuniyet, markanın yayılmasını sağlayabilecektir. Bu nedenle rehberlerin hizmet sunumları önemlidir.

Sonuç olarak, stratejik olarak yönetilmesi gereken, karmaşık ve uzun bir süreç olan destinasyon markalaşması sürecinde, markalaşmanın önündeki engellerin araştırılmasının faydalı olacağı düşünüldüğünden, rehberlerin bu konudaki görüşlerinin önem arz ettiğini söylemek mümkündür. Araştırmaya göre rehberlerin çoğunluğunun, Türkiye'deki çekiciliklerin markalaşma engeli olarak tanıtım yetersizliğini gördükleri ortaya çıkmıştır. Rehberlerin görüşlerine göre turistik çekiciliklerin markalaşma başarısı için "sunulacak 


\section{IIIIII}

Turist Rehberliği Dergisi (TURED) \& Yıl. 2020, Cilt. 3, Sayı. 1

Journal of Tour Guiding (JOTOG) \& Year. 2020, Volume. 3, Issue. 1

kaliteli bir destinasyon içinde kaliteli konaklama, kaliteli ulaşım ve kaliteli yiyecek içecek sunumu gereklidir" ama hepsinden önemlisi dünyanın uzak yerlerindeki potansiyel turistlerin bunların farkına varabilmeleri için "tanıtım" gereklidir. Etkin bir tanıtım için ise pazarlama araçlarının amaca uygun olarak, stratejik bir bütünlük sağlayacak şekilde kullanılması gerekmektedir.

Araştırmaya göre, rehberlerin büyük bir kısmı sosyal medya ve internette gezilen yerler hakkında paylaşım yapmaktadır. Sosyal medyanın ve internetin bir çekiciliğin fark edilmesinde, tanınmasında dolayısıyla markalaşmasında önemli bir yeri olduğu düşünülürse, rehberlerin bu anlamda katkı sağladığı sonucuna varılabilir. Bunun yanında rehberlerin hemen hemen hepsinin Türkiye'ye yönelik başka bir tur için talep aldıklarını belirtmeleri, hem Türkiye'deki diğer çekiciliklerin markalaşmaları hem de Türkiye'nin markalaşması konusunda katkı sağladığı ve/veya sağlayacağı sonucunu ortaya çıkarmaktadır.

Araştırma sonuçlarının, turistik çekiciliklerin markalaşma çalışmalarında turizm profesyonellerine, pazarlama uzmanlarına ve yerel yönetimlere 1ş1k tutabileceğini söylemek mümkündür. $\mathrm{Bu}$ araştırmada ortaya çıkan sonuçlar, farklı çalışmalarla genişletilebilir ve uygulamada destinasyon markalaşması sürecinde rehberlerin nasıl yer almaları gerektiği yönüyle değerlendirilebilir.

\section{Kaynakça}

Akova, O. (2015). Kentlerin Markalaşma Sürecinde Profesyonel Turist Rehberleri: Çanakkale Örneği, Yayımlanmamış Yüksek Lisans Tezi, İstanbul: İstanbul Üniversitesi Sosyal Bilimler Enstitüsü.

Arat, T. ve Bulut, H. (2019). Turist Memnuniyetinde Turist Rehberinin Rolü: Konya'da Bir Araştırma, Turist Rehberliği Dergisi (TURED), 2 (1), 31-43. DOI: 10,34090/tured.581821.

Erkol Bayram, G. (2019). Sinop İlinin Turizm Odaklı Gelişimine Dair Turist Rehberlerinin Rolleri ve Görüşleri, Turist Rehberliği Dergisi (TURED), 2 (2), 57-71.

García, J. A., Gómez and M., Molina, A. (2011). A Destination-Branding Model: An Empirical Analysis Based on Stakeholders, Tourism Management, 33.

Gržinić, J., Zanketić, P. (2008), Tourism Attractions as Products of a Tourist Attraction, International Conference ICES 2006 Transitional Challenges of EU Integration and Globalization, October 09 - 10, 2008, Sarajevo, 1-13.

Gunn, C. A. and Var, T. (2002), Tourism Planning: Basics, Concepts, Cases, (4th Edition). Taylor and Francis, London: Routledge. ISBN 0-415-93268-8, ISBN 0-415-93269-6.

Hacıŏglu, N. (2006), Seyahat Acentacıll̆̆̆ ve Tur Operatörlüğ̈̈ (6. Baskı). Ankara: Nobel Yayınc1lik.

Huang, S., Hsu, C. H. C. and Chan, A. (2010). Tour Guide Performance and Tourist Satisfaction: A Study of the Package Tours in Shangai. Journal of Hospitality and Tourism Research, 34 (1), 3-33.

Kapferer, J-N. (2008). New Strategic Brand Management: Creating and Sustaining Brand Equity Long Term / Jean- Noël Kapferer. - (4th edition).

Konecnik, M. and Gartner, W. C. (2007). Customer-Based Brand Equity for a Destination. Annals of Tourism Research, 34 (2), 400-421. http://doi.org/10.1016/j.annals.2006.10.005.

Kotler, P. (2005). A'dan Z'ye Pazarlama (11.Baskı). (Çev. A. Kalem Bakkal). İstanbul: MediaCat Yayınları.

Kültür Varlıkları ve Müzeler Genel Müdürlüğü, Müze İstatistikleri, (2019). (https://kvmgm.ktb.gov.tr/TR-43336/muze-istatistikleri.html), (Erişim tarihi: 20.09.2019).

Leiper, N. (1990). Tourist Attraction Systems. Annals of Tourism Research, 17, 367-384. 
Turist Rehberliği Dergisi (TURED) \& Yıl. 2020, Cilt. 3, Sayı. 1

Journal of Tour Guiding (JOTOG) \& Year. 2020, Volume. 3, Issue. 1

MacCannell, D. (1976). The Tourist: A New Theory of the Leisure Class. New York: Schocken Books.

Overend, D. (2012). Performing Sites: Illusion and Authenticity in the Spatial Stories of the Guided Tour. Scandinavian Journal of Hospitality and Tourism, 12, 44-54. http://doi.org/10.1080/15022250.2012.678070

Pearce, P. L. (1991). Analyzing Tourist Attractions. The Journal of Tourism Studies, 2 (1), 4655.

Pearson, D. and Pearson, T. (2016). Branding Food Culture: UNESCO Creative Cities of Gastronomy. Journal of Food Products Marketing, 1-14. http://doi.org/10.1080/10454446.2014.1000441.

Ritchie, J .R. B. and Zins, M. (1978). Culture as Determinant of the Attractiveness of a Tourism Region. Annals of Tourism Research, 5 (2).

Semone, P. and Kozak, M. (2011). Towards a Mekong Tourism Brand. Asia Pacific Journal of Tourism Research, 16 (65), 1-20.

Sipahi, G. A. ve Algür, S. (2016). Destinasyon Marka İmajına Etki Eden Unsurlar: Kuşadası Örneği. EKEV Akademi Dergisi, 20 (66).

Tasc1, A. D. and Gartner, W. (2009). A Practical Framework for Destination Branding, Tourism Branding, Communities in Action. Emerald Books.

Türkiye Seyahat Acentaları Birliği, 1618 Sayılı Seyahat Acentaları ve Seyahat Acentaları Birliği Kanunu, (2018). (https://www.tursab.org.tr/dosya/7221/1618sk05072012 tarihlideiiklikilenmihali_7221_3807623.pdf), (Erişim tarihi:14.02.2018).

Weiler, B. and Black, R. (2014). Tour Guiding Research - Insights, Issues and Implications. Channel View Publications Aspects of Tourism, UK.

Yu, X., Weiler, B. and Ham, S. (2001). Intercultural Communication and Mediatio: A Framework For Analysing. Journal of Vacation Marketing, 8 (1), 75-87.

Zillinger, M., Jonasson, M. and Adolfson, P. (2012). Guided Tours and Tourism. Scandinavian Journal of Hospitality and Tourism, 12 (1), 1-7.

Zorlu, Ö. ve Erkuş, G. (2018). Kültür Turlarında Turist Şikâyetleri ve Şikâyet Davranıșları. Turist Rehberliği Dergisi (TURED), 1 (1), 31-40.

\section{ETIK ve BILIMSEL ILKELER SORUMLULUK BEYANI}

Bu çalışmanın tüm hazırlanma süreçlerinde (veri toplama, yazım vb.), tüm etik kurallara ve bilimsel atıf gösterme ilkelerine riayet edildiğini, herhangi bir hataya mahal vermemek için yayımdan önce makalenin bir intihal programı aracılığıyla da kontrol edildiğini yazarlar beyan eder. Ayrıca yazarlar aşağıda sıralanan hususları kabul etmiştir:

1. Çalışmada yer alan ve kullanılan tüm kaynaklara, bilimsel araştırma yöntemleri ve etik ilkeler doğrultusunda atıf yapılmıștır. 2. Çalışmada tüm yazarların akademik-bilimsel olarak doğrudan ve ortak katkısı vardır.

3. Bu çalışma, yazarların özgün bir çalışmasıdır.

4. Bütün yazarlar dergiye gönderilen makaleyi görmüs ve sonuçlarını onaylamıștır.

5. Çalışmada kullanılan denek/deneklere ilişkin herhangi bir etik ihlal yapılmamış, kullanılan tüm veri toplama yöntemlerinde bilimsel etik ilkelere göre hareket edilmiştir.

6. Çalışma daha önceden bilimsel bir toplantıda sunulan özet veya bu çalışmanın daha kısa hali ise, makalede bu durum belirtilmiştir.

7. Çalışmada, hiçbir suç unsuru veya kanuna aykırı ifade bulunmamakla birlikte, araștırma yapılırken kanuna aykırı herhangi bir yöntem kullanılmamış olup, çalışma ile ilgili tüm yasal izinler alınmış ve etik kurallara uygun hareket edilmiştir.

Aksi bir durumun tespiti halinde Turist Rehberliği Dergisi’nin hiçbir sorumluluğu olmayıp, tüm sorumluluk makale yazarlarına aittir.

Tarih $\quad: 20 / 06 / 2020$

Sorumlu Yazar $\quad$ : Öğr. Gör. İlknur MAZAN 